\title{
Eriginal Anticle
}

\section{Investigation of Fungi in drinking water resources, as a source of contamination tap water in Sari, Iran}

\author{
Zabihollah Yousefi. ${ }^{1}$ *Seyed Reza Aghili. ${ }^{2}$ Raheleh Ebrahimzadeh. ${ }^{3}$ Bahar Salmanian. ${ }^{4}$
}

1-Department of Environmental Health Engineering, School of public health, Health Sciences Research Center, Mazandaran University Of Medical Sciences, Sari, Iran.

2- Department of Medical Mycology and Parasitology, School of Medicine, Mazandaran University of Medical Sciences, Sari, Iran,

3- School of public health, Mazandaran University of Medical Sciences

4- Faculty member of Farhangian University of Mazandaran, Sari, Iran

*aghili70@yahoo.com

\section{Abstract}

Background and purpose: One of the most prominent concerns for the water consumers is pathogenic microorganism contamination. Wells and underground water resources are the main resources of drinking water in Sari city, Iran. The main objectives of the research project were to explore the distribution and frequency of mycoflora in wells and underground water resources of the city and their contamination effects on humans.

Materials and methods: Three reservoirs and 18 wells or underground water resources were analyzed. Water samples were then filtered and analyzed according to the World Health Organization guidelines. Each filter and $0.2 \mathrm{ml}$ of suspension inoculated on SDA+CG media. For fungal growth, plates were incubated at $27^{\prime} \mathrm{C}$ for $7-10$ days. The fungi were identified by standard mycological techniques.

Results: Fungal colonies were isolated from all samples. From total of 160 fungal colonies isolated from wells water, 14 species of fungi were distinguished. Rhodotorula (54.4\%), Monilinia (13.7\%), Alternaria (6.9\%) were the most commonly isolated. Drechslera, Rhizopus, and Exserohilum $(0.6 \%)$ had the lowest frequency. There was no significant difference between fungal elements isolated from three major reservoirs $(\mathrm{P}>0.05)$.

Conclusion: This study revealed that resources of drinking water from an area have to monitored and if its fungal CFU be greater than a certain value, medical and health preventive measures should be taken before the water is used by human. In this context, public and private awareness should also be provided through the media, broadcasting, teachers and scholars.

[Yousefi Z. *Aghili S.R., Ebrahimzadeh R. Salmanian B. Investigation of Fungi in drinking water resources, as a source of contamination tap water in Sari, Iran, IJHS 2013; 1(1): 84-91] http://jhs.mazums.ac.ir

Key words: water quality, drinking water resources, fungal contaminated water, waterborne 


\section{Introduction}

Purity and quality of water is of paramount importance to our health (1). One of the most prominent concerns for the water consumers with attend to the quality of drinking water is pathogenic microorganisms contamination. Some fungi growing in drinking water resources cause problems in taste and odor of water. Humidity, temperature, water potential, and $\mathrm{pH}$ have a critical influence on the growth and survival of fungi $(2,3)$.

Fungi are accounted as a significant cause of water pollution due to having the ability to survive after filtration $(4,5)$. Fungi have been reported as pollutant and contaminant of all types of water, like raw water, treated water even distilled or bottled drinking water $(6,7)$. The term of "contaminated water" is used when the amount of external materials are able to adversely affect human health. The diseases that are caused by microorganisms that are most commonly transmitted in contaminated fresh water called "waterborne diseases". Presences of fungi in water have often been overlooked, but it may come as a chronic problem in drinking water distribution systems. It is thought that the threshold level for numbers of fungi that can cause problem, may be around $10^{2}-10^{3} \mathrm{CFU}$ per liter.

Many aquatic fungi, including important human pathogens are able to grow on land and water. There are a growing number of severe fungal diseases by commensally species, particularly in hosts who are immuno-compromised (8). Infection is usually occurs while drinking, bathing, washing, food preparing or consuming of food. Fungi can release sulfur compounds from the metabolic oxidation of substrates. Therefore, some fungi such as Acremonium and Penicillium, can cause unpleasant taste and malodor of water (9-11). Many species of the genus fungi particularly Aspergillus sp. are found in water and can cause kidney problem, liver disorders, allergy, intensify the burn marks, otitis and increase risk of invasive infections $(12,13)$.
Penicillium sp. is one of the most frequent of fungi, found in fresh water and its implication in allergy, asthma or other respiratory problems has been cited in many previous research studies (1416). The members of the genus Candida and Rhodotorula are considered as waterborne pathogens. Candida is the most and Rhodotorula is rare opportunistic pathogenic yeasts associated with variety of human diseases and are frequently the cause of nosocomial infections in compromised hosts (17-19). Generally, texture of the soil and climate influence the growth \& distribution of fungi (20). Wells and underground water resources are main resources of drinking tap water in Sari city.

In the last decade, several studies in Iran and other countries as a key research in determining the quality of drinking water have increases knowledge on occurrence of fungi in it (21-25). It has been established that the odds for fungal recovery are three times higher in surfacessourced water compared with ground-sourced water, and fungi are more commonly recovered from cold water and shower water than from hot tap water (22). In light of the knowledge obtained from fungal water studies, and the insufficient epidemiological knowledge about health impacts, it seems a good idea to take precautionary measures for high-risk patients.

\section{Materials and Methods}

\subsection{Sampling}

Three reservoirs and 18 wells or underground water resources were analyzed in Sari, Mazandaran province, Iran. Sari city has 3 geographic zones (southern mountain, central urban and northern coastal plain). Water samples were isolated from three reservoirs tanks, two wells in the northern region, six wells in the central area and 10 wells in the southern area of the city. 
Then 21 water samples were then filtered and analyzed according to modified method of the World Health Organization guidelines (26). Briefly, for collection of wells water, the tap was opened 2 to $3 \mathrm{~min}$ before taking the samples to pass the tube water and removing the accumulated dust and dirt on the head of the tap water. For reservoirs water, sterilized conical flasks (200ml) submerged into water in an inverted position to 4$6 \mathrm{~cm}$ depth and the flask lids were removed. All samples were collected in sterilized polystyrene bottles $(200 \mathrm{ml})$ containing sodium thiosulfate (3\%) for residual chlorine neutralization. Samples were preserved in the lab for further analysis.

\subsection{Fungi Isolation procedures}

Isolation of fungi was performed by using a membrane filtration apparatus. The procedure was based on a Norwegian standard method for analysis of microfungi in water (27), with some modifications regarding the use of media and incubation temperature and length. Briefly, $200 \mathrm{ml}$ of the sample was filtrated through sterile $0.45 \mu \mathrm{m}$ cellulose filters (Millipore) under the biological hood and near the flame (Sterile condition). Then, filters were washed with $10 \mathrm{ml}$ of sterile normal saline, by shaking for 5-6 minutes in a sterile pot in order to transfer all the filtered spores to sterile normal saline. Each filter inoculated on Sabouraud's dextrose agar supplemented with chloramphenicol (50 mg/l) and gentamycin $(50 \mathrm{mg} / \mathrm{l})(\mathrm{SDA}+\mathrm{CG})$.
The remained solution containing isolated spores was centrifuged for 10 minutes in $2000 \mathrm{rpm}$. The supernatant was removed and the residual was reached to a volume of $2 \mathrm{ml}$, and then by a sterile loop $0.2 \mathrm{ml}$ of suspension was transferred into plate of $\mathrm{SDA}+\mathrm{CG}$ media. The plates were incubated at $27^{\prime} \mathrm{C}$ for $7-10$ days, and examined weekly. The number of colonies on the agar plates was expressed as number of CFU per $100 \mathrm{ml}$ water sample. The grown fungi were identified by standard mycological techniques based upon gross cultural and microscopic morphology.

\subsection{Statistical analysis}

The frequencies and distributions of mould in the samples were calculated by using Microsoft Excel spreadsheet software for Windows XP. Results were analyzed by $\mathrm{t}$-test, at $\mathrm{p}<0.05$ confidence level.

\section{Results}

Fungal colonies were isolated from all samples studied. A total of 160 fungal colonies from Wells water were isolated. 14 species of fungi were distinguished. Rhodotorula (54.4\%), Monilinia (13.7\%), Alternaria (6.9\%) was the most commonly species isolated. Drechslera, Rhizopus, and Exserohilum (0.6\%) had the lowest frequency (Table 1). 
Table1. Frequency of fungal colony isolated from each wells water resources of drinking water of Sari, Iran, 2009

\begin{tabular}{|c|c|c|c|c|c|c|c|c|c|c|c|c|c|c|c|c|c|c|c|}
\hline \multirow{2}{*}{$\begin{array}{c}\text { Geographical Zone } \\
\text { Fungi Species }\end{array}$} & \multicolumn{10}{|c|}{ Wells located in south Zone } & \multicolumn{6}{|c|}{$\begin{array}{l}\text { Wells located in } \\
\text { Central Zone }\end{array}$} & \multicolumn{2}{|c|}{$\begin{array}{l}\text { Wells located } \\
\text { in North } \\
\text { Zone }\end{array}$} & \multirow{2}{*}{ 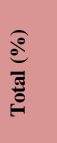 } \\
\hline & $\mathbf{A} / \mathbf{1}$ & $\mathbf{B} / 2$ & $\mathrm{C} / 3$ & $1 / 9$ & L/12 & $\mathbf{P} / \mathbf{1 3}$ & $\mathrm{Q} / \mathbf{1 4}$ & $\mathrm{R} / \mathbf{1 5}$ & $\mathrm{S} / 16$ & $\mathrm{~T} / \mathbf{1 7}$ & F/6 & G/7 & $\mathbf{H} / \mathbf{8}$ & $\mathbf{J} / \mathbf{1 0}$ & $\mathbf{K} / \mathbf{1 1}$ & $\mathrm{U} / \mathbf{1 8}$ & $\mathrm{D} / 4$ & $\mathbf{E} / \mathbf{5}$ & \\
\hline Rhodotorula & 4 & 5 & 8 & 3 & 5 & 6 & 4 & 4 & 2 & 3 & 3 & 2 & 4 & 6 & 6 & 8 & 8 & 6 & $\begin{array}{c}87 \\
(54.4) \\
\end{array}$ \\
\hline Monilinia & 2 & 1 & 2 & 3 & 1 & & & & & & 2 & 3 & 4 & 1 & 1 & 1 & 1 & & $\begin{array}{c}22 \\
(13.7)\end{array}$ \\
\hline Alternaria & & & & & & 1 & & & & & & 1 & 3 & & & 2 & 1 & 3 & $\begin{array}{c}11 \\
(6.9) \\
\end{array}$ \\
\hline Cladosporium & & & 1 & & & & 2 & 2 & & & & 2 & & & & 2 & & & $\begin{array}{c}9 \\
(5.6)\end{array}$ \\
\hline Penicillium & & & 2 & & & 2 & & 2 & 1 & & & & & 2 & & & & & $\begin{array}{c}9 \\
(5.6) \\
\end{array}$ \\
\hline Aspergillus & 2 & & & & & 1 & & & & & & & & & & & & 1 & $\begin{array}{c}4 \\
(2.5) \\
\end{array}$ \\
\hline Nigrospora & 1 & & & & & & & & & & & 1 & 1 & & & & & & $\begin{array}{c}3 \\
(1.9) \\
\end{array}$ \\
\hline Chaetomium & & & & & & & & 1 & & & & & & & & & 1 & 1 & $\begin{array}{c}3 \\
(1.9) \\
\end{array}$ \\
\hline Acremonium & & & & & & & & 1 & & & & & 1 & & & & & & $\begin{array}{c}2 \\
(1.2)\end{array}$ \\
\hline Fusarium & & & & & & & & & & & 1 & & & & & 1 & & & $\begin{array}{c}2 \\
(1.2) \\
\end{array}$ \\
\hline Drechslera & & & & & & & & & & & & 2 & & & & & & & $\begin{array}{c}2 \\
(1.2)\end{array}$ \\
\hline Rhizopus & & & & & & & 1 & & & & & & & & & & & & $\begin{array}{c}1 \\
(0.6) \\
\end{array}$ \\
\hline Exserohilum & & & & & & & & & & & & & & & & 1 & & & $\begin{array}{c}1 \\
(0.6) \\
\end{array}$ \\
\hline Sterile hyphae* & & & & & 2 & & & & & & & & 1 & & & 1 & & & $\begin{array}{c}4 \\
(2.5) \\
\end{array}$ \\
\hline Total (\%) & $\stackrel{9}{(5.6)}$ & $(3.8)$ & $\begin{array}{l}13 \\
(8.1)\end{array}$ & $(3.8)$ & $\begin{array}{c}8 \\
(5.0)\end{array}$ & 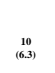 & $\left(\begin{array}{c}7 \\
(4.4)\end{array}\right.$ & $\begin{array}{c}10 \\
(6.3)\end{array}$ & $\begin{array}{c}3 \\
(1.8)\end{array}$ & $\begin{array}{c}3 \\
(1.8)\end{array}$ & $(3.8)$ & $\begin{array}{c}11 \\
(6.9)\end{array}$ & $\begin{array}{c}14 \\
(8.8)\end{array}$ & $\stackrel{9}{(5.6)}$ & $\left(\begin{array}{l}7 \\
(4.4)\end{array}\right.$ & $\begin{array}{c}16 \\
(10.09)\end{array}$ & $\begin{array}{l}11 \\
(6.9)\end{array}$ & $\begin{array}{l}111 \\
(6.9)\end{array}$ & $160(100)$ \\
\hline
\end{tabular}

*Fungusgrowth into hypha without fruit body and species of fungus was not detected by conventional methods of Mycology

The total mean CFU per $100 \mathrm{ml}$ for the positive samples were 44.4 fungal colonies. Highest frequency of colony counts (CFU per 100ml), isolated from water samples of wells were observed in the northern (the flat zone), central and south area respectively (Table 2).

Table 2. Average CFU/100ml isolated from different locations of wells water resources of Sari, Iran, 2009

\begin{tabular}{|c|c|c|c|c|c|c|c|c|c|c|c|c|c|c|c|c|c|c|}
\hline $\begin{array}{c}\text { Geographical } \\
\text { Zone }\end{array}$ & \multicolumn{10}{|c|}{ Wells located in southern Zone (high and foothill) } & \multicolumn{6}{|c|}{ Wells located in Central Zone } & \multicolumn{2}{|c|}{$\begin{array}{l}\text { Wells located in } \\
\text { Northern Zone( flat and } \\
\text { plain) }\end{array}$} \\
\hline Colonies & $\mathbf{A} / \mathbf{1}$ & $\mathrm{B} / 2$ & $\mathrm{C} / 3$ & I/9 & $\mathrm{L} / \mathbf{1 2}$ & $\mathbf{P} / \mathbf{1 3}$ & $\mathrm{Q} / \mathbf{1 4}$ & $R / 15$ & $\mathrm{~S} / \mathbf{1 6}$ & $\mathbf{T} / \mathbf{1 7}$ & F/6 & G/7 & H/8 & $\mathbf{J} / \mathbf{1 0}$ & $\mathrm{K} / \mathbf{1 1}$ & $\mathrm{U} / \mathbf{1 8}$ & $\mathrm{D} / \mathbf{4}$ & $\mathrm{E} / \mathbf{5}$ \\
\hline $\mathrm{CFU} / 100 \mathrm{ml}$ & 45 & 30 & 65 & 30 & 40 & 50 & 35 & 50 & 15 & 15 & 30 & 55 & 70 & 45 & 35 & 80 & 55 & 55 \\
\hline $\begin{array}{c}\text { Mean of } \\
\text { CFU/100ml } \\
\text { for each Zone }\end{array}$ & \multicolumn{10}{|c|}{37.5} & \multicolumn{6}{|c|}{52.5} & \multicolumn{2}{|c|}{55} \\
\hline
\end{tabular}


There was no significant difference between fungal elements isolated from three major reservoirs $\quad(\mathrm{p}<0.05)$ Rhodotorula and Cladosporium species were also the common fungal species isolated from major reservoirs water respectively (Fig 1).

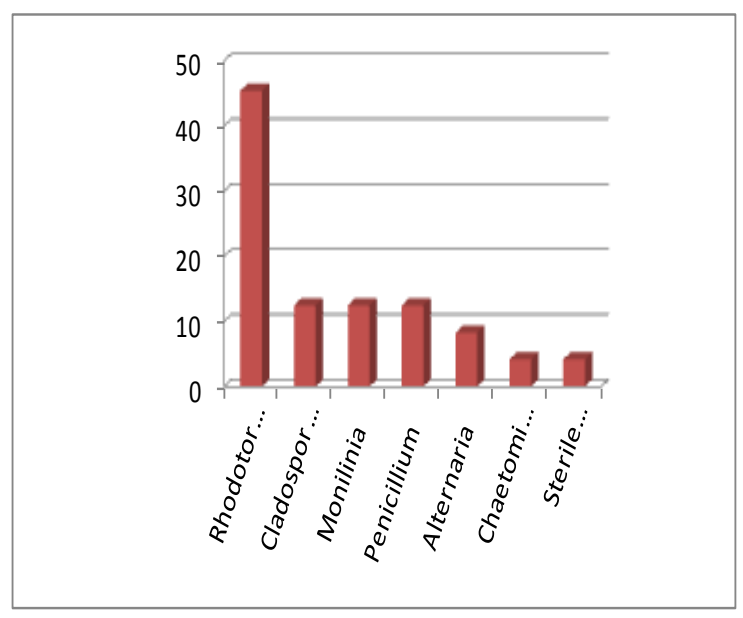

Figure 1. Percent of frequency fungi Species isolated from water reservoirs tanks

These results demonstrated that water in wells and reservoirs does has a large influence on occurrence, growth and dispersing of fungi. CFU per $100 \mathrm{ml}$ isolated from water samples of wells showed in the northern zones, that are flat, the frequency of fungi isolation was higher than other zones.

\section{Discussion}

The mycoflora has a wide range in distribution and spreads over tropical to temperate region. The growth and spread of fungi is more in rich and organic materials. As it was shown in this study, due to richness of soil in plains to high lands and high frequency of isolated fungi from water of wells, the rate of fungi is higher in this area.

However, there was no significant difference between different fungi species in these three zones $(\mathrm{P}>0.05)$. Cladosporium in high land and Alternaria in plain zone were the most ones. This may be due to the ability of these fungi for growing in a special climate and the penetration of soil into water resources as well.
Some species isolated in this study from water samples, such as Rhodotorula, Cladosporium, Penicillium and Aspergillus are opportunisms and can cause life-threatening disease for human in predisposing conditions (28) such as malignancy(29,30), transplant (31) and immunodeficiency (32). Rhodotorula is an emerging opportunistic yeast pathogen, particularly in immunocompromised patients. Many cases of fungemia associated with catheters, endocarditis, peritonitis, meningitis, and endophthalmitis are infections incited by this yeast. Felipe F. Tuon \& Silvia F. Costa (33) in review of 128 cases from literature for Rhodotorula infectin in human showed fungemia (79\%), eye infection (7\%) and peritonitis (5\%) associated with CAPD were the most common diseases which are caused by Rhodotorula. Fungi belonging to Monilinia genus are well-known pathogens of fruit trees affecting fruit production all over the word and its control is very difficult. Some species of Monilinia, as well as other fungi produce mycotoxins. Post-harvest contamination with mycotoxins causes significant impact on human health and nutrition (34). Alternaria sp. can be an opportunist human pathogen causing a hypersensitivity pneumonitis, phaeohypomycosis, onychomycosis, keratitis, otitis and extrinic asthma in individuals with atopic disease. In immunocompetent patients, Alternaria colonizes the paranasal sinuses, leading to chronic hypertrophic sinusitis. In immunocompromised patients the colonization may end up with development of invasive disease. Pastor F. J. and Guarro J. (35) had 210 reported cases of human alternarioses between 1933-2008. The most frequent clinical manifestations were cutaneous and subcutaneous infections $(74.3 \%)$, followed by oculomycosis $(9.5 \%)$, invasive and non-invasive rhinosinusitis $(8.1 \%)$ and onychomycosis (8.1\%). Immunosuppression is frequently associated with cutaneous and subcutaneous infections and rhinosinusitis. Sanjay G. Revankar and Deanna A. Sutton (36) and others, explained that melanized or dematiaceous fungi such as Alternaria, Cladosporium (37-38), Chaetomium (39), 
Drechslera (40) and Exserohilum (41), isolated from water samples in this study, are associated with a wide variety of infectious syndromes. The clinical syndromes caused by these fungi are differentiated based on histologic findings into eumycetoma, chromoblastomycosis, and phaeohyphomycosis.

These will be arbitrarily divided into allergic disease, superficial and deep local infections, pulmonary disease, central nervous system (CNS) infection, and disseminated disease.

Yi-Ming Fan, et al (42) expressed Nigrospora as a rarely opportunistic pathogen in humans. There have been 4 reports on Nigrospora-induced human eye and skin infections in the literature. However, they report the first case of Nigrospora sphaerica-induced onychomycosis in humans.

Green B.J et. al. (43) demonstrated that Alternaria, Cladosporium, Penicillium and Aspergillus cause allergy in human. Dignani MC, Anaissie E. (44) explained some Fusarium species produced infections in human. Mizukane $\mathrm{R}$ et al.(45), described that Aspergillus sp. also created different diseases in human beings i.e. Asthma, allergic sinusitis, cutaneous infection, endophthalmitis in support of possible waterrelatedness of contamination by these genus (46). Hence, this study revealed that resources of drinking water from an area must be screened and if its fungal CFU be greater than a certain value, medical and health preventive measures should be taken before the water is used by human. In this context, public and private awareness should also be provided through the media, broadcasting, teachers and scholars, so this causes people apply certain precautionary parameters before any use of water resources.

\section{Acknowledgements}

The authors gratefully acknowledge the followings: Department of Medical Mycology and Parasitology of Faculty of Medicine and Department of Environmental Health Engineering of Faculty of Health for their help in laboratory recognition and instruments and also Mazandaran University of Medical Sciences for supporting by grant and making the research possible.

\section{References}

1. Tebbutt, T.H.Y. Principles of water quality control. 1998; 5th edition. pp.1-45.

2. Nazim, S., Dawar S., Tariq M. and Zaki M.J. Quantitative estimation of mycoflora in drinking water and fruit juices of Karachi. Pak. J. Bot., 2008; 40(3): 12631268.

3. Ahmed, A., Dawar S. and Tariq M. Mycoflora associated with sugar cane juice in Karachi city. Pak. J. Bot., 2010; 42(4):2955-2962.

4. Kirk P.M., Cannon P.F., David J.C., Stalpers J.A., Ainsworth \& Bisby's Dictionary of the Fungi, 2001; 9th edn. CAB International, Wallingford,

5. Cabral D., Ferna'ndez P. Fungal spoilage of bottled mineral water. International Journal of Food Microbiology, 2002; 72: 73-76.

6. Hussain T., Hussain A., Sultana K. Study of drinking water fungi and its pathogenic effects on human beings from district Bhimber Azad Kashmir, Pakistan. Pak. J. Bot., 2011; Vol:43(5): pp:2581-2585

7. Ribeiro A, Machado AP, Kozakiewicz Z, Ryan M, Luke B, Buddie AG, Venâncio A, Lima N, Kelley J, Fungi in bottled water: a case study of a production plant. Revista Iberoamericana de Micologi'a, 2006; 23: 139-144.

8. Van Burik, J. A. and Magee, P. T. Aspects of fungal pathogenesis en humans. Ann. Rev. Microbiol., 2001; 55, 743-772.

9. Standing Committee of Analysts, The microbiology of drinking water, part 11taste odour and related aesthetic problems, 2004.

10. Camper, AK. Biofilms in drinking water treatment and distribution, P.311-332. In L.V.Evans(ed), Biofilms: Recent advances in their study and control. Harward Academic Publishers Amsterdam, The Nether londs, 2000. 
11. Hedayati, MT, Mayahi, S, Movahedi, M, Shokohi, T, Study on fungal flora of tap water as a potential reservoir of fungi in hospitals in Sari city, Iran, MYCOLOGIE MEDICALE, 2010; 21; 10-14

12. Anaissie, E. J., and S. F. Costa. Nosocomial aspergillosis is waterborne. Clin. Infect. Dis., 2001; 33:1546-1548.

13. Katsouyannopoulos, V. High level of recovery of fungi from water and dialysate in haemodialysis units. J. Hosp. Infect., 2000; 45, 225-230.

14. Denning, D. W., B. R. O'Driscoll, C. M. Hogaboam, P. Bowyer, and R. M. Niven. The link between fungi and severe asthma: a summary of the evidence. Eur. Respir. J. , 2006; 27:615-626.

15. Flannigan, B., E. M. McCabe, and F. McGarry. Allergenic and toxigenic microorganisms in houses. J. Appl. Bacteriol. Symp. Suppl., 1991; 70: 61S-73S.

16. Metzger, W. J., R. Patterson, J. Fink, R. Semerdjian, and M. Roberts. Sauna-takers disease. Hypersensitivity due to contaminated water in a home sauna. JAMA, 1976; 236:2209-2211.

17. Aronson, I. K., and K. Soltani. Chronic mucocutaneous candidosis: a review. Mycopathology, 1976; 56:17-25.

18. Gentles, J. C., and C. J. LaTouche. Yeasts as human and animal pathogens, p. 107182. In A. H. Rose and J. S. Harrison (ed.), The yeasts, vol. 1. Academic Press, Inc., New York, 1969.

19. Gomez-Lopez A, Mellado E, RodriguezTudela JL, Cuenca-Estrella M. Susceptibility profile of 29 clinical isolates of Rhodotorula spp and literature review. J Antimicrob Chemother, 2005; 55:312-6.

20. Nasser, L.A. Incidence of terrestrial fungi in drinking water collected from different schools in Riyadh region, Saudi Arabia. Pak. J. of Bio. Sci., 2004; 7(11): 19271932.
21. Gö ttlich E, van der Lubbe W, Lange B, Fiedler S, Melchert I, Reifenrath M, Flemming HC, de Hoog S, Fungal flora in groundwater-derived public drinking water. International Journal of Hygiene and Environmental Health 2002; 205: 269-279

22. Hageskal, G. Moulds in Norwegian drinking water. Occurrence and Distribution of Mould Species in Drinking Water Distribution Systems. 2007; PhD thesis, Norwegian School ofVeterinary Science, Oslo.

23. Gonc, alves AB, Paterson RRM, Lima N,. Survey and significance of filamentous fungi from tap water.International Journal of Hygiene and Environmental Health 2006a; 209: 257-264

24. Paterson RRM, Lima N,. Fungal contamination of drinking water. In: Lehr J, Keeley J, Lehr J, ingery TB (eds), Water Encyclopedia John Wiley \& Sons.2005; New York.

25. Mayahi S., Mosavi B. , Hedayati M.T., Movahedi M. , Shokohi T. Mycoflora assessment in drinking tap water (Sari, Iran). J Gorgan Uni Med Sci. 2011; 13 (4) :114-119

26. Guidelines for Drinking-water Quality Volume 2: Health Criteria and Other Supporting Information Second edition 1996, xvi + 973 pages

27. Anon. Drinking Water Regulations (in Swedish). 2003; SLVFS 2001:30. National Food Administration, Stockholm, Sweden.

28. Richardson M.D. Changing patterns and trends in systemic fungal infections. J Antomicrob Chemother, 2005; 56, 5.

29. Alliot, C., B. Desablens, R. Garidi, and S. Tabuteau. Opportunistic infection with Rhodotorula in cancer patients treated by chemotherapy: two case reports. Clin. Oncol. 2000; 12:115-117. 
30. Krcmery, V., I. Krupova, and D. W. Denning. Invasive yeast infections other than Candida species in acute leukaemia. J. Hosp. Infect., 1999; 41:181-194.

31. Warnock DW. Fungal complications of transplantation: diagnosis, treatment and prevention. J Antimicrob Chemother, 1995; 36: Suppl., B73-90.

32. Iviani MA. Opportunistic fungal infections in patients with acquired immune deficiency syndrome. Chemotherapy, 1992; 38:35-42, (suppl) 11.

33. Tuon, F. F. Costa, S. F. Rhodotorula infection. A systematic review of 128 cases from literature. Medical Mycology (Oxford), 2008; (25), p. 135-140,

34. Trias R, Bañeras L, Montesinos E, Badosa E. Lactic acid bacteria from fresh fruit and vegetables as biocontrol agents of phytopathogenic bacteria and fungi.

35. Pastor F.J., Guarro J. Alternaria infections: Laboratory diagnosis and relevant clinical features. Clinical Microbiology and Infection, 2008; 14 (8), pp. 734-746.

36. Revankar SG, Sutton DA. Melanized fungi in human disease. Clin Microbiol Rev. Oct, 2010; 23(4):884-928

37. Middleton, F. G., Jurgenson P. F., Utz J. P., Shadomy S., and Shadomy H. J. Brain abscess caused by Cladosporium trichoides. Arch. Intern. Med., 1976; 136:444-448.

38. Vieira, M. R., Milheiro A., and Pacheco F. A. Phaeohyphomycosis due to Cladosporium cladosporioides. Med. Mycol., 2001; 39:135-137.

39. Piepenbring, M., Caceres Mendez O. A., Espino Espinoza A. A., Kirschner R., and Schofer H. Chromoblastomycosis caused by Chaetomium funicola: a case report from Western Panama. Br. J. Dermatol., 2007; 157:1025-1029.
40. O'Sullivan, F. X., Stuewe B. R., Lynch J. M., Brandsberg J. W., Wiegmann T. B., Patak R. V., Barnes W. G., and Hodges G. R. Peritonitis due to Drechslera spicifera complicating continuous ambulatory peritoneal dialysis. Ann. Intern. Med., 1981; 94:213-214.

41. Peerapur, B. V., Rao S. D., Patil S., and Mantur B. G. Keratomycosis due to Exserohilum rostratum - a case report. Indian J. Med. Microbiol., 2004; 22:126127.

42. Yi-Ming F., Wen-Ming H., Wen L., GuoXue Z. Onychomycosis Caused by Nigrospora sphaerica in an Immunocompetent Man.Arch Dermatol., 2009; 145(5):611-612.

43. Green B.J., Sercombe J.K., and Tovey E.R. Fungal fragments and undocumented conidia function as new aeroallergen sources. J. Allergy Clin. Immunol., 2005; 115, p. 1043

44. Dignani MC, Anaissie E., Human fusariosis. Clin Microbiol Infect, 2004; 10(Suppl. 1):67-75.

45. Mizukane R, Sawatari K, Araki J, et al. Invasive pulmonary aspergillosis caused by aspiration of polluted water after nearly drowning (in Japanese). Kansenshogaku Zasshi., 1996; 70:1181-1185.

46. Hageskal, G. Moulds in Norwegian drinking water. Occurrence and Distribution of Mould Species in Drinking Water Distribution Systems. 2007; PhD thesis, Norwegian School of Veterinary Science, Oslo. 